\title{
NOTES
}

\section{REINSTATING VACATED FINDINGS IN EMPLOYMENT DISCRIMINATION CLASS ACTIONS: RECONCILING GENERAL TELEPHONE CO. ข. FALCON WITH HILL v. WESTERN ELECTRIC CO.}

Recently, in General Telephone Co. v. Falcon, ${ }^{1}$ the Supreme Court severely restricted the ability of private plaintiffs to bring Title VII ${ }^{2}$ einployment discrimination class actions. ${ }^{3}$ Before Falcon, some federal courts allowed across-the-board employment discrimination class actions. ${ }^{4}$ In these courts, a plaintiff alleging one type of employment discrimination could represent a class alleging several types of employment discrimination. The Falcon Court, however, relying on the commonality and typicality requirements of Federal Rule of Civil Procedure 23,5 held that class representatives alleging einployment discrimination can represent only the class of people alleging the "same harm or injury" as themselves. 6 A private plaintiff alleging discrimination in promotion practices, for example, can no longer represent a class alleging discrimination in hiring practices. ${ }^{7}$

The end of the private across-the-board approach to Title VII employment discrimination class actions means that victims of different
1. 457 U.S. 147 (1982).
2. 42 U.S.C. $\$ 2000 e-2000 e-17$ (1976).
3. See infra notes 26-33 and accompanying text.
4. See infra notes 18-21 and accompanying text and note 25 .
5. Federal Rule of Civil Procedure 23(a) provides in relevant part:
(a) Prerequisites to a Class Action. One or more members of a class may sue or be sued as representative parties on behalf of all only if . . . (2) there are questions of law or fact common to the class, (3) the claims or defenses of the representative parties are typical of the claims or defenses of the class, and (4) the representative parties will fairly and ade- quately protect the interests of the class.

FED. R. Crv. P. 23(a).

6. 457 U.S. at 156-61; accord East Tex. Motor Freight Sys. v. Rodriguez, 431 U.S. 395, 403 (1977) (quoting Schlesinger v. Reservists Comm. to Stop the War, 418 U.S. 208, 216 (1974)). This rule applies only to private actions. The Equal Employment Opportunity Commission (EEOC) has special statutory authority to bring class actions under 42 U.S.C. \& 2000e-5(f)(1) (1976) and therefore need not comply with Rule 23. Falcon, 457 U.S. at 156; General Tel. Co. v. EEOC, 446 U.S. 318,323 (1980). This note deals only with private actions.

7. This was the Lolding in Falcon. See infra notes $26-33$ and accoinpanying text. 
types of employment discrimination must be represented separately unless they can prove a "general policy of discrimination."8 Because of the difficulty of proving such a policy, ${ }^{9}$ the novelty of the exception, ${ }^{10}$ and the narrow definition of "same harm or injury,"" judgments for class representatives bringing broad class actions will often be reversed on appeal for violating the commonality and typicality requirements of Rule 23.12 These reversals generally require costly recertification of improperly represented subclasses and retrial of the substantive issues.

In Hill v. Western Electric Co. ${ }^{13}$ the Court of Appeals for the Fourth Circuit suggested a procedure to reduce the need for such recertification and retrial. The Hill court provided for reinstatement of the original trial court's findings if proper plaintiffs intervene on remand and reinstatement would not prejudice either side. ${ }^{14}$

This note first reviews the recent treatment of the "saine harm or injury" requirement and examines its probable impact on employment discrimination class action litigation. ${ }^{15}$ Next, the note analyzes the Hill proposal in light of Falcon. ${ }^{16}$ Because the Hill proposal involves reinstating findings that have been vacated, the note then analyzes the

8. Faleon, 457 U.S. at 159 n.15; see infra notes $36-37$ and accompanying text.

9. Cf. Abron v. Black \& Decker, Inc., 654 F.2d 951, 955, 961 (4th Cir. 1981) (Murnaghan, J., dissenting) (The "same harm or injury" requirement is a "procedural barrier which will effectively limit the substantive rights of minority employees under Title viI . . . . Few employers have a 'single' promotion practice from which all employees discriminatorily denied promotions suffer in exactly the same way. The Title VII employer's promotion practices would typically be numerous and varied.").

At least one court has held that a complaint failed to meet the standard required by the footnote IS exception. See Warren v. ITT World Communications, Inc., 95 F.R.D. 425,429 (S.D.N.Y. 1982); see also infra note 37 and accompanying text.

10. See infra note 37 .

11. The Falcon Court narrowly defined what is to be considered the "same harm or injury." The Court held that discrimination in hiring practices was sufficiently different from discrimination in promotion practices, thereby precluding class certification under the commonality and typicality requirements of Rule 23 . Similarly, job placement, firing, and compensation practices are arguably different. See Ladele v. Consolidated Rail Corp., 95 F.R.D. 198 (E.D. Pa. 1982) (claim that employee was paid less because of his race las no cominon questions of law or fact with claim that employee was discriminated against in promotions).

12. For an independent opinion that the footnote 15 exception will be the source of much litigation, see Employment Discrimination - ABA Convention, 51 U.S.L.W. $2141-42$ (Aug. 31, 1982).

13. 672 F.2d 381 (4th Cir.) [Hill IJ], cert. denied, 103 S. Ct. 318 (1982). The same case had previously reached the Court of Appeals for the Fourth Circuit on a different issue. In Hill v. Western Elec. Co., 596 F.2d 99 (4th Cir.) [Hill I], cert. denied, 444 U.S. 929 (1979), the Court of Appeals for the Fourth Circuit adopted the strict "same harm or injury" test on the basis of the Supreme Court's decision in East Tex. Motor Freight Sys. v. Rodriguez, 431 U.S. 395 (1977); see infra notes 23-25 and accompanying text.

14. See infra notes 54-64 and accompanying text.

15. See infra notes $18-67$ and accompanying text.

16. See infra notes $68-99$ and accompanying text. 
proposal in view of recent developinents in the law of mootness. ${ }^{17}$ The note concludes that the Hill proposal is consistent with Falcon and may save time and inoney in handling certain class representation problems.

\section{BACKground: The "SAME HARM OR INJURY" REQUiREMENT}

\section{A. The Situation Before General Telephone Co. v. Falcon}

Before Falcon, some federal courts apphed an across-the-board approach to the Rule 23 commonality and typicality requirements in Title VII employment discrimination class actions. ${ }^{18}$ These courts allowed plaintiffs alleging one type of employment discrimination to represent a class asserting several different types of einployment discrimination. ${ }^{19}$ In Johnson v. Georgia Highway Express,

17. See infra notes 100-146 and accompanying text.

18. Two cases, Oatis v. Crown Zellerbach Corp., 398 F.2d 496 (5th Cir. 1968), and Jenkins v. Umited Gas Corp., 400 F.2d 28 (5th Cir. 1968), forcshadowed the emergence of the across-theboard approach in the Court of Appeals for the Fifth Circuit. See Rutherglen, Tinle VII Class Actions, 47 U. CHI. L. Rev. 688, 709-10 (1980).

19. A number of courts applying the across-the-board approach reasoned that the very nature of Title VII actions eliminates commonality and typicality problems. See, e.g., Crockett v. Green, 534 F.2d 715 (7th Cir. 1976); Wetzel v. Liberty Mut. Ins. Co., 508 F.2d 239 (3d Cir.), cert. denied, 421 U.S. 1011 (1975); Long v. Sapp, 502 F.2d 34, 42 (5th Cir. 1974); Johnson v. ITTThompson Indus., 323 F. Supp. 1258, 1261-62 (N.D. Miss. 1971); Wilson v. Monsanto Co., 315 F. Supp. 977,979 (E.D. La. 1970). But see Wells v. Ramsay, Scarlett \& Co., 506 F.2d 436, 437-38 (5th Cir. 1975) ("One may not represent a class of which one is not a part."); Cooper v. Allen, 467 F.2d 836, 839 (5th Cir. 1972).

According to the courts employing this reasoning, the common question in Tille VII actions was simply whether there had been racial discrimination. The "Damoclean threat of a racially discriminatory policy hangs over the racial class [and] is a question of fact common to all members of the class." Johnson v. Georgia Highway Express, Inc., 417 F.2d 1122, 1124 (5th Cir. 1969) (quoting Hall v. Werthan Bag Corp., 25I F. Supp. 184, 186 (M.D. Tenn. 1966)). Typicality "lies in the common thread of discrimination." 4 H. NEWBERG, NewBerg ON CLASS ACTIONS $\$ 7983$ (1977) [hereinafter cited as H. NewBERG].

The expansive across-the-board approach was justified on a number of grounds, including congressional intent. See Long v. Sapp, 502 F.2d at 43 ('The 'across-the-board' approach has proved an effective means of implementing the congressional purpose embodied in the civil rights acts."); Mack v. General Elec. Co., 329 F. Supp. 72, 74 (E.D. Pa. 1971) (“A narrow construction of Title VII would unduly restrict, if not frustrate, the Congressional purpose reflected in the passage of this legislation."). See generally Developments in the Law-Employment Discrimination and Title VII of the Civil Rights ACt of 1964, 84 HARV. L. REv. 1109, 1113-19 (1971) [hereinafter cited as Developments].

Promoting the public interest was another reason cited in support of the across-the-board approach. Mack, 329 F. Supp. at 76 (E.D. Pa. 1971) (quoting Developments, supra, at 1220). The Mack opimion also mentioned that the across-the-board approach provided a way to protect the rights of those discriminated against but afraid to sue. Id. Furthermore, the Mack court stated that the across-the-board approach conserved time and resources. Id.; accord Rosario v. New York Times Co., 84 F.R.D. 626 (S.D.N.Y. 1979). The Rosario court stated that the across-theboard approach "avoids piecemeal examimation of an employer's alleged discriminatory practices where general discrimination is being attacked. It provides an efficient means of disposing of 
Inc. ${ }^{20}$ for example, the Court of Appeals for the Fifth Circuit let a former black employee who alleged he had been fired in violation of Title VII represent "the class harmed by the alleged discrimination in hiring, firing, promotion, and maimtenance of facilities."21 Other federal courts, however, refused to adopt this across-the-board approach. ${ }^{22}$

The Supreme Court first addressed the across-the-board approach in 1977 in East Texas Motor Freight System v. Rodriguez. ${ }^{23}$ The Rodriguez decision, however, did not clearly resolve whether across-theboard class actions violate the commonality and typicality requirements of Rule 23. Some courts held that Rodriguez precluded acrossthe-board class actions; ${ }^{24}$ other courts distinguished Rodriguez and continued to use the across-the-board approach. ${ }^{25}$

complaints in this area, especially when judicial economy is a pressing problem." Id. at 629-30. Chief Justice Burger does not share this view: "Rather than promoting judicial economy, the 'across-the-board' class action has promoted multiplication of claims and endless litigation." Falcon, 457 U.S. at 147 (Burger, C.J., concurring in part, dissenting in part).

20. 417 F.2d 1122 (5th Cir. 1969).

21. Id. at 1124.

22. Compare, e.g., Tipler v. E. I. duPont deNemours \& Co., 443 F.2d 125 (6th Cir. 1971) and Parham v. Southwestern Bell Tel. Co., 433 F.2d 421 (8th Cir. 1970) and Mack v. General Elec. Co., 329 F. Supp. 72 (E.D. Pa. 1971) (upholding across-the-board class actions) with Pointer v. Sampson, 62 F.R.D. 689 (D.D.C. 1974) and White v. Gates Rubber Co., 53 F.R.D. 412 (D. Colo. 1971) and Hyatt v. United Aircraft Corp., 50 F.R.D. 242 (D. Conn. 1970) (rejecting actoss-theboard class actions).

Some confusion was generated when certain courts of appeals failed to apply the across-theboard approach consistently. Compare, e.g., Barnett v. W.T. Grant Co., 518 F.2d 543 (4th Cir. 1975) (upholding an across-the-board claim) with Doctor v. Seaboard Coast Line R.R., 540 F.2d 699 (4th Cir. 1976) (rejecting across-the-board claim). Judge Widener of the Fourth Circuit has stated: "Admittedly, this court has not been consistent in its attitude toward the breadth of classes in employment discrimination litigation." Hill, 672 F.2d at 397 (Widener, J., dissenting).

23. 43 I U.S. 395 (1977). In Rodriguez, three Mexican-Americans sued on behalf of all Blacks and Mexican-Americans who had been "demed equal employment opportunities with the company because of their race." Id. at 399 . The plaintiffs alleged that a no-transfer rule perpetuated past discrimination by locking minorities into discriminatorily assigned positions.

The Supreme Court held that the plaintiffs "were not nembers of the class they purported to represent" and did not "possess the same interest and suffer the same injury" as the class members." Id. at 403 (quoting Schlesinger v. Reservists Comm. to Stop the War, 418 U.S. 208, 216 (1974)). Because the plaintiffs stipulated they had not been discriminated agamst when hired, "they were hardly in a position to mount a classwide attack on the no-transfer rule . . . on the ground that these practices perpetuated past discrimination and locked minorities into the less desirable jobs to phich they had been discriminatorily assigned." Rodriguez, 431 U.S. at 404.

24. See, e.g., Hill v. Western Elec. Co., 596 F.2d 99, 101-02 (4th Cir.), cert. denied, 444 U.S. 929 (1979).

25. According to the Court of Appeais for the Fifth Circuit, the problem in Rodriguez was that the Court determined at the start that the plaintiffs did not have valid individual claims:

Rodriguez involved named plaintiffs who lacked a nexus with the class as a result of the lack of merit of their individual claims.... It is not necessary that the representative 


\section{B. General Telephone Co. v. Falcon and After.}

1. The Falcon Decision. The Supreme Court settled the acrossthe-board controversy in 1982 when it decided General Telephone Co. v. Falcon ${ }^{26}$ In Falcon, the plaintiff alleged he had been demed a promotion because he was Mexican-American, but sued on behalf of a class including Mexican-Americans who had been demed employment altogether. The Court of Appeals for the Fifth Circuit, using the acrossthe-board approach, upheld the district court's certification of the class. ${ }^{27}$

The Supreme Court rejected the across-the-board approach. The Court distinguished the question whether an imdividual has been harmed by an employer's promotion practices from the question

suffer discrimination in the same way as other class members, but it is necessary that she suffer from the discrimination in some respect.

Satterwhite v. City of Greenville, 578 F.2d 987, 993 n.8 (5th Cir. 1978), vacated on other grounds, 445 U.S. 940 (1980).

This situation should be distinguished from "headless class" cases in which a plaintiff who originally alleges a proper individual claim and is a member of the certified class fails to prove his individual claim.

In such a case, the class claims would have been tried already and, provided the initial certification was proper and decertification not appropriate, the claims of the class members would not need to be mooted or destroyed because subsequent events or the proof at trial had undermined the named plaintiff' individual claims.

Rodriquez, 431 U.S. at 406 n.12.

The Satterwhite court suggested that Rodriguez only stood for the proposition that a plaintiff Inust have suffered at least some imjury before he can represent a class. Other courts distinguished Rodriguez the same way and continued to apply the actoss-the-board approach. See, e.g., Scott v. University of Del., 601 F.2d 76, 85 n.19 (3d Cir.), cert. denied, 444 U.S. 931 (1979); Bartelson v. Dean Witter \& Co., 86 F.R.D. 657, 663-65 (E.D. Pa. 1980); Rosario v. New York Times Co., 84 F.R.D. 626, 629 (S.D.N.Y. 1979); Beasley v. Griffin, 81 F.R.D. 114, 116-17 (D. Mass. 1979); Wajda v. Penn Mutual Life Ins. Co., 80 F.R.D. 303, 307-09 (E.D. Pa. 1978); Wofford v. Safeway Stores, Inc., 78 F.R.D. 460, $473-77$ (N.D. Cal. 1978); see also Note, Antidiscrimination Class Actions Under the Federal Rules of Civil Procedure: The Transformation of Rule 23(b)(2), 88 YALE L. J. $868,882-83$ (1979) ("The conflict betwcen the permissive and the rigorous approaches to the Rule 23(a) prerequisites was not settled by the Supreme Court's treatment of 23(a) in Rodriguez."). But see Hill v. Western Elec. Co., 596 F.2d 99 (4th Cir.), cert. denied, 444 U.S. 929 (1979); Tuft v. McDonnell Douglas Corp., 581 F.2d 1304, 1307-08 (8th Cir. 1978); Shipp v. Memphis Area Office, 581 F.2d 1167, 1170-72 (6th Cir. 1978), cert. denied, 440 U.S. 980 (1979). See generally Comment, The Proper Scope of Representation in Title VII Actions: A Comment on East Texas Motor Freight Systcm, Inc., v. Rodriguez, 13 HARv. C.R.-C.L. L. REV. 175 (1978). In later cases the Court of Appeals for the Fifth Circuit firmly established its interpretation of Rodriguez as not precluding across-the-board class actions. See, e.g., Shepard v. Beaird-Poulan, Inc., 617 F.2d 87, 89 (5th Cir. 1980); Davis v. Roadway Express, Inc., 590 F.2d 140, 143 (5th Cir. 1979); Camper v. Calumet Petrochemicals, Inc., 584 F.2d 70, $71-72$ (5th Cir. 1978).

Interestingly, in Payne v. Travenol Laboratories, Inc., 565 F.2d 895 (5th Cir.), cert. denied, 439 U.S. 835 (1978), a pre-Satterwhite case, the Court of Appeals for the Fifth Circuit allowed an across-the-board approach without specifically distinguishing Rodriguez.

26. 457 U.S. 147 (1982).

27. Falcon v. General Tel. Co., 626 F.2d 369, 374-76 (5th Cir. 1980). 
whether the individual's claim is typical of the class claim..$^{28}$ According to the Falcon Court, proof that the employer discriminated against the plaintiff in some way does not justify the inference that discriminatory treatment typifies the employer's promotion practices, that it pervades the coinpany, or that it exists in other practices of the employer. ${ }^{29}$

The Court was particularly concerned that if it allowed the acrossthe-board approach "every Title VII case would be a potential coinpany-wide class action." 30 The Court found "nothing in [Title VII] to indicate that Congress intended to authorize such a wholesale expansion of class-action litigation." 31 The Falcon Court also pointed out that overly broad class certification inakes it harder for courts to determine whether there is adequate class representation and inakes it more likely the einployer will not know how to defend. ${ }^{32}$ The Court also noted the potential "unfairness to the class members bound by the judgment if the framing of the class is overbroad." 33

2. The Aftermath of Falcon. Courts deciding cases arising after Falcon have abandoned the across-the-board approach. ${ }^{34}$ The Falcon decision, however, did not completely eliminate the across-the-board employment discrimination suit. The Equal Employment Opportunity Commission (EEOC) can still bring such actions because it need not comply with Rule $23 .{ }^{35}$ In addition, footnote fifteen of the Falcon opinion provides a loophole for private litigants: "Sigmificant proof that an employer operated under a general policy of discrimination conceiv-

28. Justice Stevens' opinion stated:

Conceptually, there is a wide gap between (a) an individual's claim that he has been denied a promotion on discriminatory grounds, and his otherwise unsupported allegation that the company has a policy of discrimimation, and (b) the existence of a class of persons who have suffered the same injury as that individual, such that the imdividual's claim and the class claim will share common questions of law or fact and that the individual's claim will be typical of the class claims.

Falcon, 457 U.S. at 157.

29. Id The Court added that these "additional inferences demonstrate the tenuous character of any presumption that the class claims are 'fairly encompassed' within [the plaintiffs] claim." Id at 158.

30. Id at 159 (footnote omitted).

31. Id

32. Id at 161 (quoting Johnson v. Georgia Highway Express, Inc., 417 F.2d 1122, 1125-27 (5th Cir. 1969) (Godbold, J., concurring)).

33. 457 U.S. at 161.

34. See, eg., Richardson v. Byrd, 7 LAB. ReL. Rep. (BNA) (32 Fair Empl. Prac. Cas.) 603, 605-06 (5th Cir. July 22, 1983); Wheeler v. City of Columbus, 686 F.2d 1144, 1147 n.3 (5th Cir. 1982); Falcon v. General Tel. Co., 686 F.2d 261, 261-62 (5th Cir. 1982); Jackson v. City of Belle Glade, 95 F.R.D. 384, 385-86 (S.D. Fla. 1982); Ladele v. Consolidated Rail Corp., 95 F.R.D. 198, 200-05 (E.D. Pa. 1982); Hawkins v. Fulton County, 95 F.R.D. 88, 92-94 (N.D. Ga. 1982); Nation v. Winn-Dixie Stores, Inc., 95 F.R.D. 82, 85-86 (N.D. Ga. 1982).

35. See supra note 6. 
ably could justify a class of both applicants and employees if the discrimination manifested itself in hiring and promotion practices in the same general fashion, such as through entirely subjective decisionmaking processes." 36 Courts have not yet determined what constitutes "significant proof' under footnote fifteen. ${ }^{37}$

36. Falcon, 457 U.S. at 159 n.15.

37. Several courts have upheld across-the-board class actions based on footnote 15. In Meyer v. MacMillen Publishing Co., 95 F.R.D. 411 (S.D.N.Y. 1982), a group of female plaintifis employed by MacMillan moved to certify an across-the-board class consisting of "all woinen who were, are now, or will be einployed [and] all women who applied, or would have applied for cmployment." $I d$. at 412 . The court noted that normally under Falcon employees cannot sue on behalf of unsuccessful job applicants. Id. at 414 . In this case, however, the court held that footnote 15 allowed such a suit:

While we do not yet have the benefit of further elaboration concerning the meaning of "significant proof [of] . . . a general policy of discrimination," we think the affidavits submitted by the plaintiffs meet that standard. The allegations in the affidavits concern not only discrimination in promotions, but in all aspects of employment: salaries, titles, offices, and, although to a lesser extent, hiring. For the purposes of this motion, plaintifis have made an adequate showing that the alleged discrimination "pervades" MacMillan as to all personnel decisions.

Id. at 415 .

Similarly, in Shannon v. Hess Oil Virgin Islands Corp., 96 F.R.D. 236, 242-43 (D.V.I. 1982), the court held that a class consisting of encumbent employees could be represented by applicants because the footnote 15 standard had been met. But see Warren v. ITT World Communications, Inc., 95 F.R.D. 425,429 (S.D.N.Y. 1982) (complaint failed to meet footnote 15 standard); supra note 9.

It is still not known to what extent courts will try to broaden what appears to be a narrow loophole. Although footnote 15 requires "significant proof," the Falcon opinion concedes that "racial discrimination is, by definition, class discrimination." 457 U.S. at 157. Furthermore, a plaintiff bringing a footnote 15 across-the-board class action las to show only that the employer operated under a "general" policy of discrimination, manifesting itself in various practices in the "same general fashion." The use of the word "general," coupled with a lack of explicit guidelines and a well-established tendency of many courts to preserve as much of the across-the-board approach as possible, may result simply in an across-the-board approach with a new technical proof requirement.

Recently, in Richardson v. Byrd, 7 LAB. Rel. ReP. (BNA) (32 Fair Empl. Prac. Cas.) 603, 605-06 (5th Cir. July 22, 1983), the Court of Appeals for the Fifth Circuit indicated its willingness to narrow the scope of the Falcon rule as much as possible. The district court in Richardson allowed a female plaintiff who alleged employment discrimination in hiring to represent a class consisting of employees as well as applicants. Id at 605 . The coun of appeals upheld the class certification under the Falcon footnote 15 exception. Id. According to the court, the Falcon Court found that the plaintiff's complaint provided an insufficient basis for the district court to conclude that "adjudication of his claim of discrimination in promotion would require the decision of any questions of law or fact common to assertedly discriminatory hiring practices." Id. (emphasis in original). The Richardson court reasoned that the Falcon holding did not translate into a holding that employees can never represent applicants. Id. The Richardson court noted that Falcon's footnote 15 specifically stated that an employer's "general policy" of discrimination could justify "a class of both applicants and employees." Id. (quoting Falcon, 457 U.S. at 159 n.15).

Applying this language, the Richardson court found that the plaimtiffs potential employer, a sheriff, was operating under a general pohicy of discrimination. Because the sheriff segregated male and female prisoners, and "the section of the jail available for females was smaller than the male section," the Richardson court held that the sheriff was operating under a policy that "by necessity limited the number of female deputies that could be employed by the Sheriff's Office. As 
Until courts agree on a standard of proof, appellate courts will inevitably find improper class certification because of the class representative's failure to meet the footnote fifteen standard. ${ }^{38}$ When this happens, findings made by the trial court concerning the improper portion of the originally certified class will be vacated. ${ }^{39}$ Proper plaintiffs can then sue on behalf of these sub-classes, but without the benefit of the original trial court's findimgs. These subsequent actions, therefore, will often require repeating parts of the origimal trial, at great expense. This imefficiency might be acceptable as a necessary consequence of avoiding the problems of overly broad classes identified by the Supreme Court in Falcon ${ }^{40}$ In Hill v. Western Electric Co. ${ }^{41}$ however, the Court of Appeals for the Fourth Circuit suggested that, under certaim circumstances, the inefficiency could be avoided by remstating the original trial court's findings. ${ }^{42}$

\section{HILL V. WESTERN ELECTRIC CO.}

\section{A. Background.}

In Hill, six black plaintiffs alleged that they had been discriminated against in job placement and promotions. They sought rehef on behalf of the class discriminated against in hiring, placement, and promotions. The district court certified the class on the authority of Barnett v. W.T. Grant Co. ${ }^{43}$ a decision by the Court of Appeals for the

such, both applicants and employees were adversely affected by the same practice." 17 LAB. ReL. REP. (BNA) (32 Fair Empl. Prac. Cas.) at 605-06.

Richardson is significant because it does not seem to impose a difficult proof requirement on a plaintiff who is either an applicant or an employee and who seeks to represent a class of both applicants and employees.

For another court's discussion of possible standards for meeting the footnote 15 exception, sce Nation v. Winn-Dixie Stores, Inc., 95 F.R.D. 82, 87-88, (N.D. Ga. 1982).

38. The Hill $I I$ proposal may also apply to any case in which appellate courts lold classes to be improperly certified because of the plaintiff's failure to meet the Falcon Court's "same harm or injury" requirement. See supro notes 56-64 and accompanying text.

39. Although no appellate court has yet considered the consequences of the plaintiffs failure to meet the footnote 15 standard, it is common practice to vacate findings when the plaintiff is found on appeal not to satisfy the Falcon standard. See, e.g., Eckerd Drugs, Inc. v. Brown, 102 S.CL 2952 (1982) (mein.).

40. See supra notes 30-33 and accompan;ing text.

41. 672 F.2d 381 (4th Cir.), cert. denied, 103 S. C. 318 (1982).

42. See infra notes 56-64 and accompanying text.

43. 518 F.2d 543 (4th Cir. 1978). In Barnett, a black plaintiff who worked for a trucking division of a large corporation was denied "the company's normal 60-day probationary period for fledgling over-the-road drivers because he was black." Id at 545. The district court held that the plaintiff could only represent "that group of black persons who have unsuccessfully applied for or requested road driving jobs with the Company." Id. at 547. The Court of Appeals for the Fourth Circuit reversed, citing several cases from other jurisdictions upholding the across-the-board approach. The court held that the plaintiff could represent all Blacks who had applied for over-the- 
Fourth Circuit that upheld an across-the-board approach in an analogous fact situation. 44 The class in Hill consisted of those blacks and feinalcs "who have applied for employment . . . or who will hereafter apply." 45 The district court found that Western Electric had discriminated against blacks and women in hiring, job placement, and promotions. ${ }^{46}$

In Hill $1,{ }^{47}$ the Court of Appeals for the Fourth Circuit reversed in part and remanded in part. The court interpreted the Rodriguez opinion ${ }^{48}$ strictly, requiring that the plaimtiffs allege the "same harm or injury" as all class members and rejecting the across-the-board approach. ${ }^{49}$ According to the court, because the plaintiffs were all employed, they could not represent the class of rejected job applicants. The court, therefore, vacated the district court's findings of discrimination in hiring for lack of proper class representation and remanded the hiring issue to the district court. ${ }^{50}$

Three new plaintiffs then filed inotions in the district court to intervene, pursuant to Fcderal Rule of Civil Procedure 24,51 on behalf of the class of rejected job applicants. The potential intervenors alleged that the defendant had refused to employ them because of their race. The district court interpreted the teruns of the remand as allowing inter-

road jobs, had been discouraged from applying, or had been kept ignorant of openings for overthe-road jobs because of the employer's discriminatory practices. Id. at 547 n.4. The appellate court also permitted the plaintiff to represent present, past, and future black employees who had been or would be denied proinotion to supervisory positions because of their race. Id.

44. The opinion of the Hill district court is reported at 12 Fair Empl. Prac. Cas. (BNA) 1175 (E.D. Va. 1976).

45. 672 F.2d at 384 .

46. Id. The court ordered Western Electric to "institute priority hiring and promotion of blacks and females to remedy past discrimination." Id. Moreover, the court required the company to develop and use new non-discriminatory hiring and promotion criteria. The court also awarded the plaintiffs their lost salaries "as determined by a special master." Id.

47. 596 F.2d 99 (4th Cir.) [Hill I], cert. denied, 444 U.S. 929 (1979).

48. See supro note 23.

49. In Hill I, the Court of Appeals for the Fourth Circuit refused to follow the courts that had interpreted Rodriguez as only holding that a plaintiff inust have suffered at least some injury before he would be allowed to represent a class. See supra note 25 .

50. Hill $I, 596 \mathrm{~F} .2 \mathrm{~d}$ at 107.

51. Federal Rule 24 provides as follows:

(b) Permissive Intervention. Upon timely application anyone may be permitted to intervene in an action: (1) when a statute of the United States confers a conditional right to intervene; or (2) when an applicant's claim or defense and the main action have a question of law or fact in cominon. When a party to an action relies for ground of claim or defense upon any statute or executive order administered by a federal or state governinental officer or agency or upon any regulation, order, requirement, or agreement issued or made pursuant to the statute or executive order. the officer or agency upon timely apphication may be permitted to imtervene in the action. In exercising its discretion the court shall consider whether the intervention will unduly delay or prejudice the adjudication of the rights of the original parties.

FED, R. Civ. P. 24(b). 
vention but nonetheless exercised its discretion to deny the motions, giving two reasons for its decision. First, the trial court wanted to end an already lengthy case. 52 Second, intervention would have delayed relief on the job assignment claims that had been upheld by the appellate court because intervention would have required a separate hearing on the hiring claims. The district court stated that it was "impractical if not impossible to be running part of the case liere and part before the inaster on the job assignment claims." 53

\section{B. The Hill II Proposal.}

In Hill II, s4 the Court of Appeals for the Fourtl Circuit vacated the district court's denial of the motion for intervention and remanded the case, declaring that the district court had abused its discretion. ${ }^{55}$ The court also stated that on remand "the original findings of discrimination in hiring might be reinstated were intervention allowed and the intervenors found in the process to be adequate representatives." 56 The court cited two advantages of reinstatement: conservation of judicial resources and avoidance of inconsistent decisions. ${ }^{57}$

52. Hill v. Western Elec. Co., 672 F.2d 381, 385 (4th Cir.) [Hill II], cert. denied, 103 S. Ct. 318 (1982).

53. Hill $I, 672 \mathrm{~F} .2 \mathrm{~d}$ at 385 . An alternative ground for this result may be found in Fed. $\mathrm{R}$. Civ. P. 54(b), dealing with partial entries of judgment.

54. Hill v. Western Elec. Co., 672 F.2d 381 (4th Cir.), cert. denied, 103 S. Ct. 318 (1982).

55. 672 F.2d at 387. The Hill II court discounted the delay argument, pointing out that bifurcation of proceedings is common in Title VII class actions. Western Electric, im its petition for rehearing, argued that the bifurcation referred to by the court of appeals as common in Title VIl class actions was different from the bifurcation rejected by the trial judge. "Bifurcating Title VII cases is a procedure commonly used to divide proof of liability from proof of individual damages." Petition of Appellee for Rehearing and Suggestion for Rehearing En Banc at 3, Hill v. Western Elec. Co., 672 F.2d 381 (4th Cir. March 15, 1982). In Hill II, the court of appeals held that the trial judge abused his discretion by refusing to split the case, leaving "one portion of the case in the initial stages of a Phase $I$ inquiry [the hiring claim] while the other portion proceeds to final judgment on the question of individual settlement to relief." Id. Western Electric argued that rejecting such an unusual procedure was not an abuse of discretion.

56. 672 F.2d at 387 (emphasis added). The district court's denial of the motion for intervention was oral and did not explicitly mention the possibility of reinstating the original trial court's findings. The court of appeals found that the wonld-be intervenors had presented this possibility to the court. The court of appeals therefore considered it appropriate to "take that factor into account on appeal." Id. at 387 n.2.

57. Id. at 387. The Hill II court was concerned that the would-be intervenors, if denied the right to intervene, wonld bring the class claim in a new action. By pointing out the danger of "inconsistent sequential adjudication of the critical issues," $i d$, the court presumably meant that a new trial might result in findings of fact different from the findings in the original trial. But if the defect in class representation in the original trial caused the findings to be different, it would be improper to compare any new findings to the original findings; the original findings would have been wrong. Before this argument for intervention and reinstatement is applicable, it must be true that the origimal findings were not affected by the defect in class representation. See infra notes 58-64, 69-94 and accompanying text. 
In essence, the Hill II proposal seeks to avoid repeating the original trial because of mere technical defects in class representation. The Hill II court conditioned reinstatement on a finding that the defect at the origmal trial "probably" did not affect the result. 58 The court also fashioned safeguards specifically designed to prevent injury to either party. ${ }^{59}$

To protect the defendant, the district court inust determine whether the employer would be unfairly prejudiced by reinstatement. 60 In making this determination, the district court must allow the defendant to introduce evidence of events and circumstances occurring after the findings were made that demonstrate prejudice. ${ }^{61}$ The court must, however, temper its inquiry by remenbering that any reinstated findings can be reviewed on appeal. ${ }^{62}$

To protect the plamtiff class, the district court must consider whether the intervenors support reinstatement of the findings and whether the original defect in class representation resulted froin a "technical lack of identity of interest and injury," rather than inadequate representation. ${ }^{63}$ The Hill $I I$ court reasoned that if the intervenors did not support reinstateinent, or if there was inadequate representation at the original trial, then the defect probably affected the original findings of the trial court. ${ }^{64}$

Judge Widener, dissenting in Hill II, opposed the majority's proposal for several reasons. He argued that vacated findings are absolutely void and cannot be reinstated under any circumstances. ${ }^{65}$ Moreover, he stated that the majority's proposal was inconsistent with

58. $672 \mathrm{~F} .2 \mathrm{~d}$ at 388 .

59. See infra notes 61-64 and accompanying text.

60. $672 \mathrm{~F} .2 \mathrm{~d}$ at 389.

61. Id. at $391-92$.

62. Id. at 389.

63. Id. One court has cited this language to support its holding that a class need not be decertified after the original plaintiff is found to be an inadequate class representative provided the class was certified before the inadequacy was determined. In Scott v. City of Anniston, 682 F.2d 1353 (11th Cir. 1982), a class was certified pursuant to a stipulation. After remand on a jifferent issue, the district court found the original plaintiffs to be inadequate class representatives. The district court, therefore, disunissed the otherwise viable class claim.

The Court of Appeals for the Eleventh Circuit held that it was error for the district court to Jecertify the class. According to the court, there was "no indication that the representation was Jeficient or less than vigorous." Id. at 1357. The court cited Hill II for the proposition that the "determination of imadequacy [of class representation] . . . may have been concerned only with a :echnical lack of identity of interest and injury between representative and class." Id. (quoting Hill $I I, 672$ F.2d at 389 ).

64. Hill $I I, 672$ F.2d at 388-89.

65. Id. at 397-99 (Widener, J., dissenting). 
the Falcon "same harm or injury" requirement. ${ }^{66}$ According to the dissent, the Hill $I I$ proposal would enable a district court to conduct a class action without following Falcon. The class could correct any representation problem arising on appeal through intervenors and seek reinstatement of the findings. ${ }^{67}$

As the dissent illustrated, the Hill $I I$ proposal appears to be at least a technical violation of the Falcon rule that plaintiffs must allege the "same harm or injury" as the class nembers; the proposal purports to give legal effect to findings made at a trial in which the plaintiffs did not allege the "same harm or injury" as the class members. Whether the Hill II proposal actually contravenes the Falcon rule, however, can be more accurately determined by examining the policies behind the rule.

\section{The Compatibility of the Hill II Proposal. With Falcon}

In rejecting the across-the-board approach in favor of the "same harm or injury" requirement, the Falcon Court recited three policy concerns: 1) avoiding prejudice to the defendants, 2) avoiding prejudice to the plaintiff class unembers, and 3) avoiding practical problems for the trial court.68

\section{A. Prejudice to the Defendants.}

The Falcon Court's first concern was that across-the-board class actions might be unfair to defendants. Courts may require an employer to prove that an individual was not discriminated against, but asking an employer to prove that he has never discriminated agaimst anyone in the class would be overly burdensome. ${ }^{69}$ Moreover, proving the absence of such pervasive discrimination is more difficult for the

66. Id at 395-97 (Widener, J., dissenting). Judge Widener could not cite Falcon, of course, because the case had not yet been decided. Instead, he cited Rodriguez, a case the Court of Appeals for the Fourth Circuit had interpreted as supporting the "same harm or injury" requirement. See supro notes $26-33,48-49$ and accompanying text.

Judge Widener asserted two additional grounds. First, he argued that the district court did not abuse its discretion in denying the motion for intervention because of the delay involved and the potential for prejudice to the defendants resulting from having to defend an overly broad, "unmanageable" action. 672 F.2d at 392-93 (Widener, J., dissenting). Second, Judge Widener argued that the district court did not abuse its discretion because none of the intervenors were members of the class. Id. at 393-95 (Widener, J., dissenting).

67. Id. at 397-99 (Widener, J., dissenting).

68. See supra notes $28-33$ and accompanying text.

69. Folcon, 457 U.S. at 157-61. The Folcon Court did not say that it was impossible for an employer to defend adequately against an across-the-board class claim, just that it was difficult. Id. at $160-61$. 
employer because the issue is not closely related to what the plaintiff must prove to support his individual claim.

When the plaintiffs satisfy the Falcon "same harm or injury" requirement, however, there is substantial similarity between the individual and class claims. It is therefore not unreasonably difficult for the employer to defend both claims at the same trial. The Falcon footnote fifteen exception to the abolition of the across-the-board class action is presumably justified on similar grounds. To bring a footnote fifteen across-the-board class action the plaintiffs must prove that a general policy of discrimination exists and manifests itself throughout the employer's practices. ${ }^{70}$ Both the class claim and the individual claim will be based on the general policy of discrimination. Thus, defending against the individual claim will be similar to defending against the class claim.

The Falcon Court's holding was directed at preventing improper across-the-board class actions from getting started. The Hill $I I$ proposal, however, is applicable only after an across-the-board class has been incorrectly certified and the class issues tried. The employer will already have defended against the across-the-board class claims without the presence of proper class representatives. The Falcon Court's original concern about prejudice to the defendant therefore translates into a concern whether, because of representation defects, the einployer actually defended madequately, causing the trial court to make adverse findings.

The Hill II proposal addresses this concern. According to the proposal, the trial court must decide whether the representation defect "did or did not probably affect the merits." 11 The court also must decide whether the defendant "will be unfairly prejudiced by the reinstatement."72 Thus, if the representation defect made it so hard for the employer to defend that it "probably" resulted in the trial court making prejudicial findings, then such findings should not be reinstated. ${ }^{73}$

70. 457 U.S. at 157 n.15; see supra notes $36-37$ and accoinpanying text.

71. Hill II, 672 F.2d at 388 . More specifically, the Hill II court stated that the general inquiry the trial court is to make when considering reinstatement is whether the representation defect "did or did not probably affect the merits in a way unaking reinstatement inappropriate." Id. The phrase "in a way ınaking reinstateınent inappropriate" presumably adds the conditions that the change be inaterial and prejudicial. See infra notes 72-73 and accoinpanying text.

72. Hill II, 672 F.2d at 388 .

73. If the trial court does reinstate its original findings, the defendants have two additional protections: the right to appeal the findings for substantive review as if there had never been a certification error and the right to present evidence of events and conditions arising after the original findings were made that indicate prejudice to his side. Id. at 391 ; see supra text accompanying notes $61-62$. 
As stated before, the "same harm or injury" requirement is designed in part to ensure that the employer will be able to defend itself adequately against all claims. ${ }^{74}$ Implicit in this aspect of the Falcon requirement is the notion that the class representative's failure to meet the "same harm or injury" test not only might inake it harder for the employer to defend, but will likely make it harder for the employer to defend. Otherwise, the "same harm or injury" requirement would not protect the employer's ability to defend. Thus, violation of the "same harm or injury" requirement seems to raise a presumption that the employer will not know how to defend properly-in other words, a presumption of prejudice.

The Hill II court did not incorporate this presumption into its proposal becanse it did not expressly allocate the burden of proof. To be consistent with the Falcon Court's presumption of prejudice to the defendant, the Hill II proposal should require that the intervenors prove that the original defect in class representation did not affect the court's findings on the merits. ${ }^{75}$

74. See supra note 32 and accompanying text.

75. The Hill $I I$ opinion offers little guidance for a court making such a determination. Arguably, if the defendants would have conducted the earlier litigation differently had the intervenors been the original named plaintiffs, the defect in representation possibly "infected" the merits. In Dickerson v. United States Steel Corp., 582 F.2d 827 (3d Cir. 1978), certain class members who were not named plaintiffs testified at the trial and were later permitted to intervene. The district court granted them relief based on their testimony. See Dickerson v. United States Steel Corp., 439 F. Supp. 55 (E.D. Pa. 1977). The Court of Appeals for the Third Circuit reversed, pointing out that

the defendants' trial strategy was based on the assumption that the class-member witnesses' testimony was relevant only to the class-wide claim, or, perhaps, the individual claim of the named plaintifis. Defendants, in deposing and cross-examining the witnesses, focused on the allegations of the class-action racial discrimination; defendants had no reason to challenge individual allegations of wrongdoing not predicated on classwide discrimination.

$582 \mathrm{~F} .2 \mathrm{~d}$ at 832 . If the intervenors in Dickerson had been named plaintiffs at the trial, the defendants would have conducted their case differently. Thus, the intervenors should not be granted relief.

The Dickerson court did not suggest what the relationship should be between the change in the defendants' conduct of their litigation and the merits of the case. The court did not require as a condition 10 a finding of prejudice to the defendants, for example, that the change in the conduct of the defendants' case "necessarily" or "probably" affected the merits. The court merely found" that because the defendants would have conducted their case differently there was "severe" prejudice. Id.

The converse of Dickerson is Mullaney v. Anderson, 342 U.S. 415 (1952). In Mullaney, after permitting new plaintiffs to join on appeal in order to correct a newly discovered standing problem, the Supreme Court noted that joinder was proper because the earlier presence of the new parties would not "have in any way affected the course of the litigation." Id. at 417. The.Mullaney Court also did not specify a required relationship between earlier joinder and the outcome of the case. As in Dickerson, the likely explanation is that the Court decided that because there definitely would have been no effect on the outcome of the case, there was no need to establish a required relationship. 


\section{B. Prejudice to the Class Members.}

A second concern of the Falcon Court was "the potential unfairness to the class members bound by the judgment if the framing of the class is overbroad."76 The Hill II proposal is designed to address this concern. To protect the plaintiff class from prejudicial findings the district court must consider whether reinstatement would be unfair to the class. ${ }^{77}$ Reinstatement presumably would be unfair to the class if the representation defect "probably" affected the findings made by the origmal trial court to the detriment of the class.

The Hill II court suggested two considerations for assessing whether the representation defect "probably" affected the findings. The first consideration is "whether the new class representative desires or resists reinstatement."78 "If properly qualified new representatives are satisfied with generally favorable findings . . . it can reasonably be assumed that the class members' primary interests in fairness . . . have been served."79 Intervenors must be adequate representatives before reinstatement will be considered, ${ }^{80}$ and thus they will be assumed to act

Dickerson and Mullaney suggest that one factor affecting the outcome of a case is any change in the way one side conducts its case because of a defect in representation. A court applying the Hill II proposal should consider whether potential changes to a party's strategy make it "probable" that the merits were affected by the defect in representation.

76. Falcon, 457 U.S. at 16l. According to the Falcon Court, the commonality and typicality requirements of Rule 23(a) "serve as guideposts for determining whether . . . the named plaintiff's claim and the class claims are so interrelated that the interests of the class members will be fairly and adequately protected in their absence." Id. at 157 n.13. These requirements "tend to merge" with each other and with the adequacy of representation requirement. Id. If the commonality and typicality requirements are not met, the class may not be adequately represented.

The Falcon Court also pointed out the possibility that the across-the-board approach could result in a judgment unfavorable to the class. Id. at 161. Citing Judge Godbold's concurring opinion in Johnson v. Georgia Highway Express, Inc., 417 F.2d 1122 (5th Cir. 1969), see supra notes 20-21 and accompanying text, the Court identified "the error of the 'tacit assumption' underlying the across-the-board rule that 'all will be well for surely the plaintiff will win and manna will fall on all members of the class.'" Falcon, 457 U.S. at 161 (citing Johnson, 417 F.2d at 1127 (Godbold, J., concurring)). The defect in class representation impticit in across-the-board class actions could cause the class's claim to be inadequately advanced in a way that harms the whole class, just as the defect could cause the employer's defense to be inadequate. The dissimilarity between the proof required to establish the representatives' individual claims and the proof required to establish the class claim makes it harder for a plaintiff not meeting the Falcon "same harm or injury" requirement to adequately bring the class claim. Cf. supra note 69 and accompanying text (analyzing how the dissimilarity in proof makes it harder for the employer to defend).

77. Hill II, 672 F.2d at 388-89.

78. Id. at 388 .

79. Id. at 389.

80. Id. at 390 ("If a proposed intervenor is found not fornally qualified to act as a class representative, the intervention inquiry as to that person obviously need proceed no further. If the district court finds any of the proposed intervenors formally qualified to represent the class it should then reconsider the motion for intervention ....."). 
for the benefit of the class. ${ }^{81}$ Under the Hill $I I$ proposal, if the intervenors do not want the original findings to be reinstated, then it is assumed that the class does not desire reinstatement either. Presumably, the class's opposition to reinstatement suggests that the original class representation was so inadequate that it "infected" the findings of the original trial court. 82

It does not necessarily follow from the intervenors' opposition to reinstatement, however, that the defect in representation affected the findings. Although the intervenors' resistance to reinstatement may be evidence that the original findings were prejudicial to the class, there is no implicit causal connection between resistance and "infected" inerits. ${ }^{83}$ Other motives might lead the intervenors to resist reinstateinent. For example, if the original findings were not sufficiently favorable to the class, intervenors might not. support reinstateinent, preferring to take the chance that a new trial would yield more favorable findings. Such a decision nnight be made in the interests of the class, but it would not necessarily indicate that the original defect in representation affected the inerits. Intervenors would want a new trial if they thought for any reason that they would have a good chance for more favorable findings. ${ }^{84}$ Therefore, district courts sliould be wary of undue reliance on imtervenors' opposition to reinstatement. ${ }^{85}$

\section{Id. at 389 .}

82. Id at 388 .

83. See id at 391 (The desires of the intervenors for reinstatement "can be taken as an indication that the class, for its part, considers that the representation provided the class members' interests in litigation . . . was 'fair and adequate.' " (emphasis added)). Presumably the converse is true: resistance to reinstatement by the intervenor may be taken as an indication that the class does not consider its interests to be adequately protected.

84. For example, a class reprsentative, acting for the benefit of the class, would probably want a new trial if the representative had hired better counsel, had located better witnesses, or had unearthed helpful information. Because the intervenors probably will not volunteer matter such as new information or theories without an extensive discovery process, the trial court will often not be aware of these factors. Discovering other factors such as the intervenors' behef that the trial judge or jury simply erred in the first trial and will not do so again would involve an analysis of the findings themselves. It may be true, however, that the court will be limited to just such an analysis rather than directly evaluating the intentions of the intervenors because of a lack of better information. When information that indicates the intervenors' resistance to reinstatement is not based on inadequate prior class representation is revealed to the court, the court should not allow reinstatement.

85. In their Petition for Rehearing and Suggestion for Rehearing En Banc, Western Electric argued that considering the desires of the intervenors in determining whether to allow reinstatement would allow proper plaintiffs to wait until findings are reached at the first trial before deciding whether to validate the findings by intervening and requesting reinstatcment. Two factors minimize this possibility. First, the would-be intervenors would risk losing at trial and then carrying the burden of showing that the named plaintiffs were unproper on appeal. Second, even if the intervenors are willing to assume this risk, the trial court could consider their motives in making its decision whether to reinstate. 
The second consideration is whether the defect in class representation "was based solely upon a formal lack of identity of interests and injury between representative and class or upon demonstrated ineffectiveness of representation."86 The Hill II court reasoned that, to the extent the defect in representation is based on inadequate representation as well as "technical lack of identity of interest and injury,"87 the defect inay affect the determination of the inerits. ${ }^{88}$ Furthermore, to the "extent inadequacy is based solely upon lack of sufficient identity of interest, any presumed adverse effect on the merits stemming from this may in fact be utterly belied by the outcome." 89

This language responds to the Hill $I I$ dissent's criticism that the Hill II proposal robs the Falcon "same harm or imjury" requirement of its "virtue." 90 One virtue of the Falcon requirement is that it prevents inadequate representation of the class by requiring a sufficient identity of interests between the class and the class representative. ${ }^{91}$ Implicit in this virtue is the notion that if there is insufficient identity of imterests, then inadequate representation is not only possible, but likely. Otherwise, the "same harm or injury" requirement would not protect the class's interest in adequate representation. The failure of the class representative to meet the "same harm or injury" requirement, however, does not necessarily mean that the class representation will be inadequate. Courts applying the Hill II proposal must judge whether the class representation was in fact inadequate by analyzing the outcome of the original trial.92 The Hill II proposal does not rob the "same harm or injury" requirement of its virtue because the proposal does not mandate reinstatement unless the danger the Falcon Court sought to prevent-madequate representation in fact-is not present.

The Hill II proposal could, however, rob the Falcon requirement of some of its virtue if the courts do not allocate properly the burden of proof. Just as the failure of the class representative to meet the "same harm or injury" requirement creates a presumption of prejudice to the defendant, ${ }^{93}$ the failure gives rise to a presumption of prejudice to the

86. Hill 11,672 F.2d at 388.

87. Id. at 389.

88. Id.

89. Id.

90. Id. at 397 (Widener, J., dissenting).

91. See Falcon, 457 U.S. at 161 (justifying "same harm or injury requirement" on grounds of potential unfaimess to class).

92. The trial court's analysis, on remand, of whether class representation in the earlier proceeding was adequate will involve the same problems as the court's analysis of whether the defect in class representation changed the findings sought to be reinstated to the detriment of the defendants. See supra note 75.

93. See supra note 75 and accompanying text. 
class. To preserve this presumption, the intervenors, as the moving parties, should have the burden of showing no prejudice to the class, just as the intervenors should have the burden of showing no prejudice to the defendants. ${ }^{94}$

\section{Practical Problems.}

The third concern of the Falcon Court was that "without reasonable specificity the court cannot determine whether the representation is adequate."95 A trial court confronted with a proposed across-theboard class inay find it difficult to determine if a proposed class representative will adequately represent class interests.

The Hill II proposal requires a court to examine a prior proceeding to determine if there was adequate representation. ${ }^{96}$ In making this determination, the court would have available for its consideration not only the proposed class and class representative but the record of the prior proceeding. Because the court would be exercising hindsight instead of foresight, its task would be easier, and the Falcon concern would be mitigated.

There may, however, be other practical problems in applying the Hill $I I$ proposal. For example, the proposal envisions a hearing at which the opposing sides argue the reinstatement issue. ${ }^{97}$ This additional hitigation conld arguably consume the judicial time and resources saved by the remstatement. On the other hand, refusing reinstatement in cases in which it might be appropriate would constitute an even greater waste of judicial resources. ${ }^{98}$ Furthermore, requesting a reinstatement hearing might become a dilatory tactic in intervention cases.

A possible solution to these problems is to make the decision to hold a hearing on reinstatement discretionary with the court. If the trial court believes the case appropriate for such a hearing, then a hearing could be held. 99 Because of the danger of prejudice, however, find-

94. Id.

95. Falcon, 457 U.S. at 161 (quoting Johnson v. Georgia Highway Express, Inc., 417 F.2d 1122, 1126 (5th Cir. 1969) (Godbold, J., concurring)).

96. See supra notes $86-92$ and accompanying text.

97. Hill II, 672 F.2d at 391-92.

98. Cf. Mullaney v. Anderson, 342 U.S. 415, 417 (1952) ("To dismiss the present petition [for joinder] and require the new plaintiffs to start over in District Court would entail needless waste and runs counter to effective judicial administration . . . ."). For discussions of Mullaney, sec supra note 75 , infra note 143 .

99. The trial court's decision whether to allow reinstatement would not be easy. The trial court would focus on a prior proceeding that may have taken place years ago. The inquiry is also largely subjective. The court would be examining factors such as the motives and desires of the intervenors, see supra notes 78-85 and accompanying text, and whether the defendants would have 
ings should not, in any case, be reinstated without a hearing.

\section{Reinstating Vacated Findings}

The viability of the Hill $I I$ proposal depends on whether findings vacated because of a defect in class representation can be given any legal effect upon reinstatement. The Hill $I I$ dissent argued that they cannot. ${ }^{100}$ The inain argument against reinstating vacated findings is that the defect in class representation inade the class claim inoot. If the class claim was inoot, then the original trial court did not have a "case or controversy" under article $\mathrm{III}^{101}$ and thus did not have jurisdiction to make the findings sought to be reinstated.

There are two arguments for reinstating vacated findings under the Hill II proposal. First, the class claim was never inoot and therefore reinstatement is proper whenever the defect in representation did not prejudice the defendants. Second, even if the trial court lacked jurisdiction to make findings concerning the class claim, jurisdiction can be conferred retroactively.

\section{A. Mootness of the Class Claim.}

Whether the failure of named plaintiffs to meet the commonality and typicality requirements of Rule 23 renders the class claim inoot hinges on the article III "case or controversy" requireinent. ${ }^{102}$ The "case or controversy" requirement has two elements; it "involves both

conducted their prior hitigation differently had the intervenors been named plaintiffs in the original proceeding, see supra note 75.

Another concern of the Falcon Court was that "every Title VII case would be a potential company-wide class action." 457 U.S. at 159 (footnote omitted). The Court stated that it found "nothing in the statute to indicate that Congress intended to authorize such a wholesale expansion of class-action hitigation." Id. This concern is probably not a separate issue in analyzing the Hill II proposal for two inain reasons.

First, there is a spht of authority over whether Congress intended to authorize private acrossthe-board class actions when it passed Title VII. Compare, e.g., H. NEWBERG, supra note 19, \$ 7973a ("The Congressional purpose expressed in the civil rights acts, of eliminating job bias, is best accomplished by permitting any individual alleging unlawful discrimination to sue to rectify all prejudicial activities involved.") and Developments, supra note 19, at I220 ("the "across-theboard' class action conception goes a long way toward effectuating the public interest") with Rutherglen, supra note 18, at 724 ("Congressional policy, as expressed in Title VII and its legislative history, does not reflect a judgment of sufficient force and clarity to displace the usual operation of rule 23.").

Second, even if Congress did not intend to authorize across-the-board class actions when it passed Title VII, it is reasonable to assame Congress and the Falcon Court shared the same concerns. If the Hill II proposal does not violate the three Falcon concerns, then it probably also does not violate congressional expectations.

100. Hill II, 672 F.2d at 397-98 (Widener, J., dissenting).

101. U.S. Const. art. III. \$2, cl. 1.

102. Id. 
constitutional limitations on federal-court jurisdiction and prudential limitations on its exercise."103 The constitutional limitation arguably focuses on a minimal requirement of concrete adverseness. ${ }^{104}$ Prudential limitations include such policies as refusing standing to litigate generalized grievances ${ }^{105}$ or to assert third-party rights. ${ }^{106}$

Plaintiffs who try to bring Title VII class actions must ineet both individual and class representative standing requirements. ${ }^{107}$ These requirements address distinctly different issues. Individual standing requirements refer to the article III "case or controversy" requirement, ${ }^{108}$

103. Gladstone, Realtors v. Village of Bellwood, 441 U.S. 91, 99 (1979) (quoting Warth v. Seldin, 422 U.S. 490, 498 (1975)); see also Duke Power Co. v. Carolina Envtl. Study Group. Inc., 438 U.S. 59, 80 (1978) ("Our prior cases have, however, acknowledged 'other limits on the class of persons who may invoke the courts' decisional and remedial powers,' which derive from general prudential concerns . . . .) (quoting Warh; 422 U.S. at 499) (citation omitted); Williamson, Foirh Amendment Standing and Expectations of Privacy: Rakas v. Illinois and New Directions for Some Old Concepts, 31 U. FLA. L. REV. 831, 861 (1979) (Standing "involves both constitutional and prudential limitations on federal court jurisdiction and its exercise.").

104. See, eg., LeBel, Standing After Havens Realty: A Critique and an Alternative Framework for Analysis, 1982 Duxe L.J. 1013, 1033 ("Aricle III . . arguably requires only an adversary relationship between the parties on opposite sides of the hitigation.").

105. See United States v. Richardson, 418 U.S. 166, 178 (1974) (standing refused because plaintiff's grievances were "shared with "all members of the publie" ") (quoting Ex parte Levith, 302 U.S. 633, 634 (1937)).

106. See Worth, 422 U.S. at 499. Some commentators have argued that such prudential limitations have "becoine a surrogate for decisions on the merits." Tushnet, The New Law of Standing: A Plea for Abandonment, 62 CORNeLl L. REv. 663, 663-64 (1977). "Decisions on questions of standing are concealed decisions on the merits of the underlying . . . claim. The Court finds tanding when it wishes to sustain a claim on the merits and demies standing when the claim would be rejected were the merits reached." Id. at 663; see also Williamson, supra note 103, at 835 (Rakas v. Illinois, 439 U.S. 128 (1978), "represents the first case in which the United States Supreme Court has expressly acknowledged the close relationship between the concept of standing and the merits of the substantive claims presented by the litigants.").

107. Both mootness and standing are aspects of the general doctrine of "justiciability" under the "case or controversy" requirement. Mootness is "the doctrine of standing set in a time frame." United States Parole Comm. v. Geraghty, 445 U.S. 388, 397 (1980). Standing is the satisfaction of erticle III requirements at the beginning of the hitigation; mootness is the satisfaction of article III requirements throughout the litigation. Id. For discussions of individual and class representative standing requirements, see H. NEWBERG, supra note 19, 88 7973-7983; C. WRIGHT, LAW OF FEDeral. Courts 872 (3d ed. 1976); C. Wrioht \& A. Miller, Federal Practice and Procedure 88 1759-1771 (1975). The distinction between "individnal" and "class representative" standing is unsettled. The requirement that the plaintiff be a member of the class arguably overlaps the Rule 23 commonality and typicality requirements. But see Falcon, 457 U.S. at 157 n.13 ("The commonality and typicality requirements . . . tend to merge . . . . Those requirements . . . also tend to merge with the adequacy of representation requirement."). Newberg argues that individual standing requirements should be analyzed separately from the adequacy of representation requirement. For an argument that the typicality requirement is superfluous, see Comment, Federal Rule of Civtl Procedure 23(a)(3) Typicality Requirement: The Superfuous Prerequisite 10 Maintaining a Class Action, 42 OHIO ST. L.J. 797 (1981).

108. U.S. Const. art. III, 82 , cl. 1. 
the Title VII "aggrieved person" requirement, ${ }^{109}$ and arguably the requirement that the plaimtiff be a member of the class. ${ }^{110}$ Class representative standing requirements concern Rule 23 prerequisites such as a common question of law or fact, typicality of claims or defenses, and adequate representation."11 Because the "same harm or injury" requirement comes from the commonality and typicality requirements of Rule 23, the failure to meet the "same harm or injury" requirement is a defect in class representative standing. Therefore, the failure to meet a class representative standing requirement, such as the "same harm or injury" requirement, does not necessarily imply that an individual standimg requirement, such as the "case or controversy" requirement, is not met.

The constitutional element of the "case or controversy" requirement is met whenever the Hill II proposal is applicable. To satisfy this element the parties must allege "such a personal stake in the outcome" 112 as to ensure that "the dispute sought to be adjudicated will be presented in a form historically capable of judicial resolution." 113 This "personal stake" standard is minimal,114 arguably calling only for an adversarial relationship betwcen the parties. ${ }^{115}$ In cases in which the Hill II proposal is applicable this adversarial relationship requirement is satisfied because the parties, by definition, will have hitigated the

109. 42 U.S.C. $\$ \$ 2000 e-5(b), 2000 e-5(f)(3)$ (1976). Most courts have given a broad meaning to the term "aggrieved person." These courts "hold that the "conditions of employment' nomenclature of Title VII protects the total work environment." H. NEWBERG, supra note 19, $\$ 7973 a$. The "conditions of employment" nomenclature comes from 42 U.S.C. \& 2000e-2(a) (1976):

It shall be unlawful employment practice for an employer-

(1) to fail or refuse to hire or to discharge any individual, or otherwise to discriminate against any individual with respect to his compensation, terms, conditions, or privileges of employment, because of such individual's race, color, religion, sex, or national origin ....

Thus, "any employee functioning in an atmosphere affected by discrimination has suffered the requisite injury in fact to make him or her an aggrieved person." "H. NEwBERG, supra note 19, 8 7973a ; see also Carr v. Conoco Plastics, 423 F.2d 57 (5th Cir.), cert. denied, 400 U.S. 951 (1970) (standing of plaintifis upheld even though they were not personally and directly exposed to the discrimination); EEOC Case No. YSF 9-108, CCH EEOC Decisions (1973) I 6030 (June 26, 1969) (a white employee was "aggrieved" by discrimination directed at blacks because the situation was a condition of his work environinent).

110. For a discussion of membership in the class as an additional individual standing requirement. see H. NEwBERG, supra note 19, 87973 d. Individual standing is a prerequisite for asserting a class claim and also satisfies constitutional requirements.

111. Federal Rule 23(a) is set out in relevant part, supra note 5.

112. Baker v. Carr, 369 U.S. 186, 204 (1962).

113. Flast v. Cohen, 392 U.S. 83, 101 (1968).

114. See LeBel, supra note 104, at 1037 ("If the constitutional barriers to standing are lowered to the level suggested above, all but the few suits that can be labeled 'collusive' will clear the Article III hurdle.") (footnote omitted); Tushnet, supra note 106, at 680 ("Thus, standing in its pure article $I 11$ form imposes only a very minor limitation on the availability of a federal forum.").

115. See supra note 104. 
class claim in a fully adversarial proceeding without prejudice to either side.

The "case or controversy" requirement's prudential concerns are not controlling in cases in which the Hill II proposal is applicable. For example, the prudential limitation on plaintiffs asserting third-party rights does not apply. The Supreme Court, in Warth v. Seldin, stated that "Congress may grant an express right of action to persons who otherwise would be barred by prudential standing rules." 116 Congress authorized class actions by approving Rule 23 , thereby circumventing the prudential limitation on third-party causes of action. ${ }^{117}$

It is also inappropriate to bypass the merits of cases in which the Hill II proposal is applicable by invoking other prudential limitations. The proposal saves judicial time and resources. ${ }^{118}$ Moreover, the proceeding by definition will have been fair. ${ }^{119}$ Invoking the "case or controversy" requirement's prudential limitations in such cases would waste time and money and would contravene long-standing antidiscrimination policies.

This note's conclusion that the class claim is not noot in cases in which the Hill II proposal is applicable is consistent with the two most recent Supreme Court decisions linking the "case or controversy" requirement to class claims. In Deposit Guaranty National Bank v. Roper, ${ }^{120}$ the district court refused to certify a class, ruling that the class did not meet the requirements of Rule of 23(b)(3).121 The defendant then tried to settle the case with the named plaintiffs, offering to pay them the maximum sum they might have recovered from their individual claims. The plaintiffs rejected the offer. The district court entered judgment in favor of the plaintiffs based on the defendant's settlement offer. The plaintiffs appealed the district court's class certification ruling, despite the defendant's argument that the entry of judg-

116. 422 U.S. 490,501 (1975).

117. See Tushnet, supra note 106, at 679 ("By providing for class actions within the Federal Rules of Civil Procedure, Congress conferred standing on [plaintiffs] who, absent congressional action, would not have been allowed to litigate the underlying substantive issues.").

In Sosna v. Iowa, 419 U.S. 393 (1975), the Supreme Court held that post-centification failure of the plaintiffs individual claim did not moot the class claim. Professor Tushnet states that Sosna stands for the proposition that "a resrospective determination that a case has been litigated in a concrete setting allows a court to reach the merits of a controversy. Article III seems to require no more." Tushnet, supra note 106, at 679 (emphasis added). Concluding that cases in which the Hill II proposal is applicable are not moot involves just such a retrospective determination.

118. See supra note 57 and accompanying text.

119. See supra notes 58-64 and accompanying text.

120. 445 U.S. 326 (1980).

i21. The distria court opinion is not reported. 
ment rendered the case moot. The Court of Appeals for the Fifth Circuit rejected the mootness argument and ordered the district court to certify the class because Rule 23 had been complied with. ${ }^{122}$

The Supreme Court affirmed, holding that although the district court's entry of judgment ended the plaintiffs' individual claims, the plaintiffs still had an assertable economic interest in the certification of the class. ${ }^{123}$ Specifically, the Roper Court noted that certification would enable the named plaintiffs to spread their litigation costs. ${ }^{124}$

In a companion case, United States Parole Commission v. Ger$a g h t y,{ }^{125}$ the plaintiff's individual claim was rendered moot just before the district court demed certification. The Supreme Court held that the plaintiff could appeal the ruling denying class certification even though his individual claim was moot. According to the Geraghty Court, the article III "case or controversy" requirement has two parts. First, there must be a continuing "live" controversy. Second, there inust be some party with a "personal stake" in the outcome of the case. ${ }^{126}$ In applying the "personal stake" requirement, the Court held that although the plaintiff had never alleged any personal interest in the certification question, ${ }^{127}$ he nonetheless satisfied the requirement because he "continue[d] to vigorously advocate his right to have a class certified" in a concrete factual setting capable of judicial resolution. ${ }^{128}$

Under Roper and Geraghty the class claim in a Hill $I I$ situation is not rendered moot by the class representative's failure to meet the coinmonality and typicality requirements of Rule 23 . The first requirement-that there be a continuing "live" controversy-is met because the class controversy has actually been litigated. ${ }^{129}$

The original class representative contemplated by the Hill $I I$ proposal also meets the liberal "personal stake" standard estabhished in Roper and Geraghty. The Geraghty Court emphasized the "flexible character" of the article III requirements. ${ }^{130}$ The Court stated that "the

122. Roper v. Consurve, Inc., 578 F.2d 1106, 1111-16 (5th Cir. 1978), affd sub nom. Deposit Guar. Nat'l Bank v. Roper, 445 U.S. 326 (1980).

123. Deposit Guar. Nat'l Bank v. Roper, 445 U.S. 326, 328-40 (1980).

124. Id. at 334 n.6, 338 n.9.

125. 445 U.S. 388 (1980).

126. Id. at 395-97. This two-part test has been acknowledged. See Zeidman v. J. Ray McDermott \& Co., 651 F.2d 1030, $1041-42$ (5th Cir. 1981); Ford v. Umited States Steel Corp., 638 F.2d 753, 760 (5th Cir. 1981).

127. See Geraghty, 445 U.S. at 420 (Powell, J., dissenting).

128. Id. at 404.

129. The Geraghty Court found a "hive" controversy because class members were trying to imtervene. 445 U.S. at 396; see also Ford v. United States Steel Corp., 638 F.2d 753, 760 (5th Cir. 1981). The Hill $I I$ proposal by definition involves intervention.

130. Geraghty, 445 U.S. at 400. 
purpose of the 'personal stake' requirement is to assure that the case is in a form capable of judicial resolution." 131 That is, there must be "sharply presented issues in a concrete factual setting and self-interested parties vigorously advocating opposing positions." 132 The Roper Court characterized an economic interest in spreading hitigation costs as a sufficient "personal stake." 133 In a Hill II situation, the plaintiff, by qualifying as an "aggrieved person" within the meaning of Title VII, ${ }^{134}$ probably satisfies the "personal stake" requirement. ${ }^{135}$ Because a named plaintiff in a Hill $I I$ situation would by definition have hitigated the claims without prejudice to either side, he would ineet the "personal stake" requirement by having asserted "sharply presented issues"136 and by "vigorously advocating opposing positions." $137 \mathrm{Fi}-$ nally, the plaintiff would have an economic interest in spreading hitigation costs similar to that of the plaintiff in Roper. ${ }^{138}$

\section{B. Retroactive Jurisdiction.}

The second rationale for allowing reinstatement of vacated findings-retroactive assignment of jurisdiction-applies even if the class claim was inoot and the trial court was therefore without power to unake findings concerning the class. The United States Court of Appeals for the Fifth Circuit developed this retroactive jurisdiction concept in Finn v. American Fire and Casualty Co. ${ }^{139}$ Finn arose on remand from the Supreine Court's holding that the federal district court liad no jurisdiction over the case, due to the lack of complete

131. Id at 403.

132. Id.

133. Roper, 445 U.S. at 334 n.6, 338 n.9; see Geraghty, 445 U.S. at 400.

134. See supra note 109 and accompanying text.

135. In Horn v. Associated Wholesale Grocers, lnc., 555 F.2d 270 (10th Cir. 1977), the court allowed a plaintiff to represent the class simply because he had a "present, past and future interest" as an employee in stopping his employer's discrimination. Id. at 277. See generally Comment, The Headless Class Action: The Effect of a Named Plaintif's Pre-Certification Loss of a Personal Stake, 39 MD. L. REv. 121, 141-52 (1979).

136. Geraghty, 445 U.S. at 403.

137. $1 d$.

138. The decision of the Court of Appeals for the Eleventh Circuit in Scott v. City of Anniston, 682 F.2d 1353 (1lth Cir, 1982), see supra note 63, supports the proposition that a "case or controversy" can exist between a class improperly represented and a defendant. In holding that a class need not be decertified after the original plaintiff was found to be an inadequate class representative provided the class was certified before the determination of inadequacy, the Scott court addressed the question whether a continuing controversy existed. According to the court, although cenain relief the class had requested was no longer necessary because the defendant had altered its behavior, the class could still pursue other relief. $682 \mathrm{~F} .2 \mathrm{~d}$ at 1358 . This holding implicitly recognizes the existence of a controversy at least as to the other retief between the improperly represented class and the defendant.

139. 207 F.2d 113 (Sth Cir. 1952), cert. denied, 347 U.S. 912 (1954). 
diversity among the parties. ${ }^{140}$ The plaintiffs sought to dismiss as to certain dispensable parties and thereby perfect diversity and jurisdiction. The trial judge, however, refused to reinstate his original findings, pointing out his lack of power to inake thein in the first place. ${ }^{141}$

The Court of Appeals for the Fifth Circuit reversed, holding that the plantiff's dismissal as to the dispensable parties would be given retroactive effect, so long as the remaining defendant had not been prejudiced in the prior proceeding because of the jurisdictional error. ${ }^{142}$ In the absence of such prejudice, the court noted, "[e]very consideration of proinptness and dispatch in the administration of justice deinands that the first trial should be preserved." 143

Thcse same considerations of promptness and dispatch apply in a Hill $Y I$ situation. The intervention of new plaintiffs essentially corrects a "jurisdictional" error. Because the Hill $I I$ proposal requires that reinstatement not prejudice either side, retroactive assignment of jurisdiction to the original trial proceedings would be consistent with Finn and would allow reinstatement of the trial court's findings.

This argument is also consistent with the established principle that amendinents correcting jurisdictional defects in coinplaimts are to be hiberally allowed to prevent dismissals because of technicalities. ${ }^{144}$ Such amendments are allowed even after final judgment has been en-

140. The Supreme Court's opinion is reported at 341 U.S. 6 (1951).

141. 207 F.2d at 115. The opinion of the district court is not reported.

142. Id. at $115-16$.

143. Id. at 116. The Court of Appeals for the Finh Circuit applied Finn in Eklund v. Mora, 410 F.2d 731 (5th Cir. 1969). The EkJund court held that when "the first trial was free from error apart from a jurisdictional matter, a new trial was not mandatory and judgment could be entered on the original verdict after the correction of the jurisdictional flaw." Id. at 732.

In Burleson v. Coastal Recreation, Inc., 572 F.2d 509 (5th Cir. 1978), the Court of Appeals for the Fith Circuit held that a winning plaintiff dissatisfied with the damages awarded could not overturn the trial courr's judgunent for lack of jurisdiction when an indispensable party to the judgenent could be dismissed to correct the jurisdictional error. The court cited Finn as controlling.

Similarly, in Mullaney v. Anderson, 342 U.S. 415 (1952), the Supreme Court permitted new plaintiffs to join after trial in order to correct a standing problem that had been raised on appeal. According to the Court, the joinder of the new plaintiffs merely put "the principal, the real party in interest, in the position of his avowed agent." Id at 417. The Court also noted that earlier joinder would not have affected the course of the original litigation, and that to deny joinder would waste judicial resources. Id.

Finn, Eklund, Burleson, and Mullaney stand for the proposition that a court lacking jurisdiction may be deemed to have had jurisdiction if, during the same case, the jurisdictional error is corrected without prejudice to the defendants.

144. See Miller v. Davis, 507 F.2d 308, 311 (6th Cir. 1974) ("Amendment to establish jurisdiction is broadly permitted, so as to . . . avoid dismissals on technical grounds."); FED. R. Clv. P. 15(a) ("leave [to amend] shall be freely given when justice so requires"). 
tered.145 Amending a complaint after final judgment in effect assigns jurisdiction retroactively. The Hill $I I$ proposal is consistent with this practice because it, in effect, also corrects a technicality after a final judgment has been entered. Moreover, these amendinents are confined to the same case, cousistent with the coustitutional notion that jurisdiction is meant to be defined in terms of a case, rather than an issue. ${ }^{146}$

\section{Conclusion}

A district court implementing the Hill $I I$ proposal on remand should adopt the following procedure. The court must first determine whether the imtervenors are adequate class representatives. If they are not, intervention should be denied. If the intervenors are proper plaintiffs, intervention should be permitted, and the court must consider whether to allow reinstatement of its previous findings.

145. See Cohen v. Wlinois Inst. of Technology, 581 F.2d 658, 662 (7th Cir. 1978), cert. denied, 439 U.S. 1135 (1979) (although amendment is generally not permitted after a final decision, "an amendment can be allowed with leave of the Court of Appeals."); Eklund v. Mora, 410 F.2d 731, 732 (5th Cir. 1969) ("Upon leave of the court a party may amend defective allegations of jurisdiction, even after judgment has been entered or an appeal taken."); 28 U.S.C. $\$ 1653$ (1976) ("Defective allegations of jurisdiction may be amended, upon terms, in the trial of appellate courts.").

146. The Constitution refers to "cases," not "questions." U.S. ConST. art. III. The doctrine of pendent jurisdiction permits a federal court to assume jurisdiction over state claims related to federal claims. If the federal claim, the basis for jurisdiction, is dismissed during trial, the court can decide the state claim because the court has already been deemed to have jurisdiction over the "case." The relationship between the state and federal claims determines the scope of the "case." Retroactive jurisdiction in a situation in which the Hill II proposal is applicable never violates this relationship requirement because the findings sought to be reinstated arise out of the same claim that intervention has given the court the power to decide. There does not seem to be a logical distinction between a case that has "technical" jurisdiction at the beginning, and then loses it, and a case that lacks "technical" jurisdiction at the beginning and then acquires it. In the first situation, jurisdiction is deemed to exist throughout the case. In the latter situation jurisdiction also can be deemed to have existed throughout the case without violating constitutional requirements. See generally C. Wright, LAW of Federal Courts $\$ 19$ (3d ed. 1976); 13 C. WrioHT \& A. Miller, Federal Practice ANd Procedure \& 3567 (1975). This "same case" requirement distinguishes cases in which the Hill $I I$ proposal is applicable from the line of cases holding that vacated findings have no res judicata effect. See, e.g., Continental Casualty Co. v. Canadian Universal Ins. Co., 605 F.2d 1349 (5th Cir.), cert. denied, 445 U.S. 929 (1979); Simpson v. Motorists Mut. Ins. Co., 494 F.2d 850 (7th Cir.), cert. denied, 419 U.S. 901 (1974); De Nafo v. Finch, 436 F.2d 737 (2d Cir. 1971). But cf. Dunlop v. Rhode Island, 398 F. Supp. 1269 (D.R.I. 1975) (vacated holding of prior case has no collateral estoppel effect, but findings of fact of prior case may be adopted if no new evidence is presented). The argument against the Hill $I I$ proposal would be that because vacated findings cannot be given legal effect as binding precedent, they cannot be given legal effect by being reinstated. The res judicata line of cases is distinguishable, however, because in those cases courts are prohibited from giving legal effect to vacated findings in cases different from the one in which the findings were made. To justify reinstating findings in a res judicata situation, it would have to be proper for a court in one case to retroactively apply its jurisdiction to a different case. The Hill $I I$ proposal only involves retroactive assignment of jurisdiction to the "same case." 
Reinstatement should be allowed only when neither side is prejudiced. To determine if there would be prejudice, the district court should consider holding a hearing at which the central inquiry would be whether the defect in class representation at the original trial "probably" affected the findings sought to be reinstated. If the district court finds that the prior defect in class representation did not "probably" affect the merits, then reinstatement should be allowed. The intervenors should, however, have the burden of proving that the findings were not affected.

When applied in this manner, the Hill II proposal is consistent with the Falcon Court's purposes for establishing the "same harm or injury" requirement. The Hill II proposal's requireinents that there be no prejudice to either side mirror the Falcon Court's concerns. The likelihood that the Hill II proposal can save considerable time and resources argues for its availability in appropriate cases.

Robert P. Monyak 